
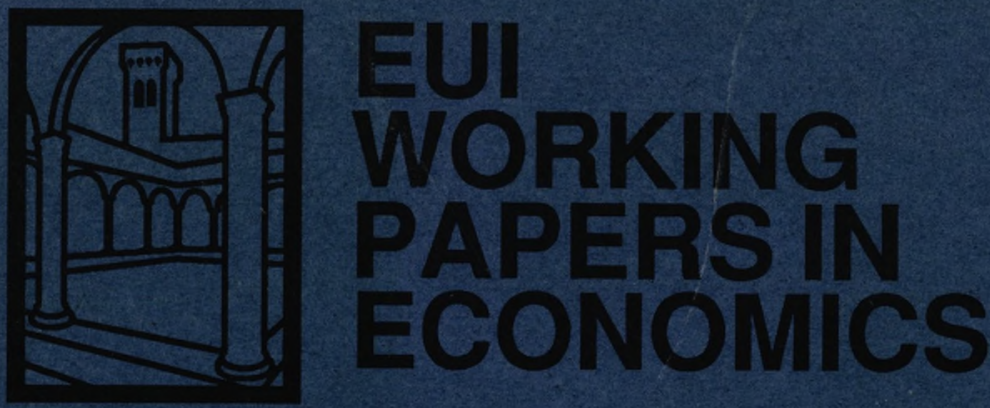

EUI Working Paper ECO No. 92/61

\title{
The Occupational Success of Young Men Who Left School at Sixteen
}

Sara Connolly, John Mickuewright and

STEPHEN NickrLL 
European University Library

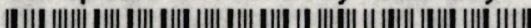

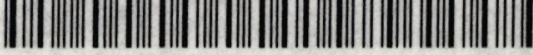

30001001357211

\section{Please note}

As from January 1990 the EUI Working Paper Series is divided into six sub-series, each sub-series is numbered individually (e.g. EUI Working Paper LAW No. 90/1). 


\section{EUROPEAN UNIVERSITY INSTITUTE, FLORENCE ECONOMICS DEPARTMENT}

EUI Working Paper ECO No. 92/61

The Occupational Success of Young Men Who Left School at Sixteen SARA CONNOLLY, JOHN MICKLEWRIGHT and STEPHEN NICKELL 
All rights reserved.

No part of this paper may be reproduced in any form without permission of the authors.

(C) Sara Connolly, John Micklewright and Stephen Nickell Printed in Italy in February 1992

European University Institute

Badia Fiesolana

I-50016 San Domenico (FI)

Italy 


\title{
THE OCCUPATIONAL SUCCESS OF YOUNG MEN WHO LEFT SCHOOL AT SIXTEEN
}

\author{
Sara Connolly,* John Micklewright** and Stephen Nickell***
}

November 1991

* St Hilda's College, Oxford

** European University Institute and Queen Mary and Westfield College, London

*** Institute of Economics and Statistics and Nuffield College, Oxford

\section{$\underline{\text { Abstract }}$}

In 1974, the majority of 16 year old boys in Britain left full-time education, this being the earliest legal opportunity. In the simplest human capital model, variations in years of schooling prior to labour market entry are the driving force behind earnings differentials at given levels of experience. Yet for the majority of young people in Britain this simple model is inapplicable because they have no schooling beyond the compulsory level. It is therefore of interest to see what determines the enormous variation in success in the labour market which befalls this group of young men. We look at those boys who left school at 16 in 1974 and analyse their occupational success in 1981 measured by the average gross hourly earnings (over the male labour force as a whole) in the relevant occupation, obtained from the Department of Employment's New Earnings Survey. The sample we consider is drawn from the National Child Development Study (NCDS) panel which is based on all individuals born in Britain in the week of March 3-9, 1958.

\section{Acknowledgements}

We are most grateful to Joan Payne and to the NCDS User Support Group at City University for assistance with the data, to the ESRC for financial help under project F0023 2294, and to Joan Payne again for valuable comments on an earlier draft. We also thank two referees for their suggestions. 


\title{
THE OCCUPATIONAL SUCCESS OF YOUNG MEN WHO LEFT SCHOOL AT SIXTEEN
}

\author{
Sara Connolly,* John Micklewright** and Stephen Nickell***
}

November 1991

* St Hilda's College, Oxford

** European University Institute and Queen Mary and Westfield College, London

*** Institute of Economics and Statistics and Nuffield College, Oxford

\section{$\underline{\text { Abstract }}$}

In 1974, the majority of 16 year old boys in Britain left full-time education, this being the earliest legal opportunity. In the simplest human capital model, variations in years of schooling prior to labour market entry are the driving force behind earnings differentials at given levels of experience. Yet for the majority of young people in Britain this simple model is inapplicable because they have no schooling beyond the compulsory level. It is therefore of interest to see what determines the enormous variation in success in the labour market which befalls this group of young men. We look at those boys who left school at 16 in 1974 and analyse their occupational success in 1981 measured by the average gross hourly earnings (over the male labour force as a whole) in the relevant occupation, obtained from the Department of Employment's New Earnings Survey. The sample we consider is drawn from the National Child Development Study (NCDS) panel which is based on all individuals born in Britain in the week of March 3-9, 1958.

\section{Acknowledgements}

We are most grateful to Joan Payne and to the NCDS User Support Group at City University for assistance with the data, to the ESRC for financial help under project F0023 2294, and to Joan Payne again for valuable comments on an earlier draft. We also thank two referees for their suggestions. 


\section{INTRODUCTION}

In 1974, the majority of 16 year old boys in Britain left full-time education, this being the earliest legal opportunity. ${ }^{1}$ In the simplest human capital model earnings, variations in years of schooling prior to labour market entry are the driving force behind earnings differentials at given levels of experience. Yet for the majority of young people in Britain this simple model is inapplicable because they have no schooling beyond the compulsory level. It is therefore of interest to see what determines the enormous variation in success in the labour market which befalls this group of young men. In what follows, we undertake the following investigation. We look at those boys who left school at 16 in 1974 and analyse their occupational success in $1981 .^{2}$ We take as our measure of occupational success, the average gross hourly earnings (over the male labour force as a whole) in the relevant occupation, obtained from the Department of Employment's New Earnings Survey. The sample we consider is drawn from the panel data provided by the National Child Development Study (NCDS) which is based on all individuals born in Britain in the week of March 3-9, 1958.

Aside from the fact that they constitute a majority of the population, our focus on 16 year-old school leavers, despite also having information on later leavers, deserves comment. Since the last available observation we have on the sample is for 1981 , this group has been in the labour force for long enough (seven years) to have settled into a level of occupation which gives some indication of their likely lifetime career pattern. If we compare this group with those who stayed on at school, many of the latter will have been in the labour force for only a brief period and their observed occupation level may give a misleading picture of their longer term prospects. So an investigation of occupational success which covers the whole NCDS sample ${ }^{3}$ may lead to false inferences being drawn unless great care is taken in the interpretation of the results. However, focussing on 16 year-old school leavers, while it enables us to compare like with like, does itself lead to problems of interpretation. The key fact to 
bear in mind is that our results are conditional on the individual leaving school at 16. So, for example, if we discover that variable $x$ raises occupational earnings by $y$ percent, this does not measure the "full" impact of variable $x$ if this same variable also raises the probability of staying on after 16 and if increased schooling raises earnings. The $y$ percent simply measures the impact of $x$ on occupational earnings given that the individual leaves school at 16 . This conditioning statement will not be made each time we present a result but it is always there implicitly and results must be interpreted in this light.

In Section 2 we discuss different possible influences on occupational success and outline our strategy for investigating these. Section 3 describes the data and the tests and allowances we make for possible selection bias brought about through missing data from the NCDS panel. Section 4 contains results including those obtained by using a fixed-effects estimator to determine the contribution to occupational success of post-entry events. Section 5 concludes and assesses some of the implications of the results.

\section{OCCUPATIONAL EARNINGS}

Some occupations rank more highly than others in terms of earnings. A part of this variation arises from the fact that individuals have to be compensated for variations in conditions of work in terms of danger, comfort and the like (see Marin and Psacharopoulos 1982, for example). Leaving this aside, one of the major factors is the reward to skill in the broadest sense of the word. Since skills take time (foregone earnings) and effort to acquire, they must be rewarded otherwise no-one would bother to acquire them. This is the foundation of the human capital model of earnings but it not the only factor. Many occupations have barriers to entry of various kinds. Some require specific periods of training which may or may not include some test of successful completion. Entry onto the training course may or may not require school leaving qualifications or some other evidence of ability or suitability. Even if 
there is no explicit period of training, the latter factors may come into play and, indeed, judgements may be made on individual characteristics such as energy, ambition, sociability, accent and the like. Restrictions on entry into an occupation may themselves raise rewards in the occupation over and above the necessary market return to foregone earnings during training. Furthermore, since capital markets are not perfect, access to financial capital may be a prerequisite for undertaking the long periods of training required in some occupations even if the individual concerned has the necessary ability and qualifications. Some individuals, for example, may simply not be able to afford to take up an apprenticeship because of the long period of relatively low pay which this entails and despite the fact that the future returns may make this a good investment.

Turning to the particular individuals we are looking at, the key questions are, what are the determinants of access to, and choice of, higher paying occupations? As Blau and Duncan observed in their seminal analysis in the US, occupational success "is the outcome of the lifelong process in which ascribed status at birth, intervening circumstances and earlier attainments determine the level of ultimate achievement" (1967, p.20). In the context of the preceeding paragraph, family background (including genetic factors) and environment determine "ability" as well as the development of skills of various kinds including social skills. A proportion of a person's marketable ability and skill is thus due to influences imputed to the individual by the circumstances of his birth and childhood. These factors may also affect the quality of formal schooling. This will, in its turn, combine with the earlier influences to be reflected in formal measures of schooling success which in our sample, are of two kinds. The first are scores in standardised tests of reading, mathematics and general ability taken at different stages of childhood. The second come in the form of standard school leaving qualifications such as CSE and 'O' levels. The former are essentially concerned with basic attainment whereas the latter measure factual knowledge to a greater extent. Furthermore, the formal qualifications are also important in the sense that they are used explicitly to determine entry into certain 
occupations. In part, however, the measures of schooling success may represent individual achievement which is independent of ascribed factors.

At the point of leaving school, other factors may also be important. Family background is still relevant because entry to certain occupations may require access to funds as well as personal contacts and the like. Direct evidence of this is provided by Atkinson, Maynard and Trinder (1983) in the UK and Osterman (1980) in the US. 4 Also, local labour market conditions may be important here on the demand side although in 1974 overall demand conditions were relatively buoyant and since the school leaving age had been raised from 15 to 16 in 1973, the 1973 cohort of leavers was small thereby increasing the demand for school-leavers in 1974.5

Events in the period between leaving school in 1974 and the observation date in 1981 provide us with many significant determinants of occupational success. In particular the acquisition of further qualifications and general labour market history, as measured by the number of job changes and unemployment incidence, can be expected to be of major importance because of their impact on the acquisition of human capital. In some respects, however, these are of less interest since they are either obvious or difficult to interpret. For example, we may discover that the achievement of a certain post-school qualification leads to a higher occupation. But this may be almost a tautology since the achievement of the qualification may be a necessary condition for entry into the higher occupation. The association in the data then merely reflects the entry requirements to various occupations, facts which can be gleaned rather more easily from a standard careers manual. On the other hand, for example, we may find that frequent job changers end up in lower occupations. This is susceptible to two quite disparate interpretations. Frequent job changing may be the result of demand conditions in the local labour market or some kind of discrimination - that is, of factors exogenous to the individual. On the other hand it might be the consequence of factors resulting from the individual's own choices. For example, young persons might change jobs frequently to enhance their career or simply because they have a restless nature. We make some attempt to discriminate between these two interpretations when 
we consider our fixed effects model in Section 4.

In the light of these remarks, we use the following investigative strategy in a regression analysis of occupational earnings. We begin by looking at the impact of family background at birth. This will reveal the full impact of those variables on the occupational success of 16 year old school leavers. We then include various ability measures as captured by test scores thereby ascertaining the full impact of these variables. This will also enable us to determine, from the decline in the family background effects, the extent to which these effects are operating through their impact on ability or in a more direct fashion through their effect on the acquisition of social skills, for example.

The next step is to introduce school-leaving qualifications and other background variables such as the extent of poverty in the home. We thereby determine the full impact of these variables, given our measures of basic attainment, and hence obtain a measure of the relative importance of basic attainment scores as against formal qualifications. Finally we introduce those factors which relate to the seven year period in the labour market. Here we are particularly interested in the extent to which the pre school-leaving variables retain their explanatory power or whether they simply operate through their impact on the acquisition of further training and qualifications or on job changing and other relevant facets of employment history. At each step we can test the hypothesis that the influences proxied by the new included variables have no joint effect, conditional on those variables already in the model which pick up the earlier influences. We therefore attempt to provide some answers to questions such as that posed by Heath (1981) as to whether "ascribed characteristics like social origins continue to have a direct influence ... even after one has passed through the educational system" (p.140). 


\section{DATA}

Our measure of occupational success is the natural logarithim of average gross hourly earnings across employed men of all ages in the individual's occupation at age 23 in 1981. We use the 1981 New Earnings Survey (NES) to provide information on earnings and hours which we map onto the 5 digit KOS coding of occupation recorded in the National Child Development Study (NCDS) microdata (further details are given in the Data Appendix). ${ }^{6}$

We restrict our attention to males so as to avoid the much larger problem of non-participation at age 23 that would occur with young women. Our main equations use a sample from the NCDS which consists of the 1,514 young men who had left school at age 16 by September 1974, who had an occupation coded (current or last) in 1981 and for whom information was present at each of the sweeps of the NCDS panel which we use to construct explanatory variables. We need, for example, information from the parental interview at birth and at 16, and the results of tests and exams taken while at school. These requirements imply that there are substantial numbers of early school leavers in the 1981 sweep of the panel for whom we do not have all the necessary data. The 1981 survey collected information on a total of 3,853 Britishborn young men who left school at the minimum legal age but there are "holes" in the panel for some 60 per cent of this potential sample. This is a common situation with panel data (although it is one which is frequently ignored) and we explore the effect of this missing data problem in three ways.

First, we use standard sample-selection techniques to try and ensure consistency of the parameter estimates provided by the sample with complete data; unobservable influences on whether data were collected at a particular sweep of the panel may be correlated with unobservable determinants of occupational success. We therefore estimate a binary model of the probability of complete data with the 3,853 cases referred to above using information collected at birth and at 23 to construct explanatory variables. Then, following Heckman (1979), we can insert the estimate 
of the inverse of the Mills ratio (assuming normality of errors) provided by this model into our regressions of occupational success which are run on the sample of complete data only. ${ }^{7}$

The results from estimating this binary model by maximum likelihood are given in Table 1 where we have assumed that the probability of complete data takes the logit functional form (the calculations of the estimated inverse Mills ratios therefore follow the procedure suggested by Lee, 1983). (The means of the explanatory variables are shown in the Data Appendix.) The probability of complete data is up to 10 percentage points higher compared to the excluded category (class 5) if the father's social class at the time of the child's birth was 1-4 (the differences between these classes not being significant). A mother who stayed on at school past the minimum age is not significantly associated with data loss (information on the father's schooling was not collected in 1958 and thus cannot be used in this equation) but inability of the mother to provide information on her father's occupation appears to be a significarit predictor of later missing data problems. The probability of complete data is lowest if birth was in London or the South-East, being some 5-10 per cent lower than the group of regions which form the base category (the North, Yorkshire, North Midlands, the South and Wales). Birth in the South-West or Scotland is associated with higher probabilities than in these regions. We see that complete data is more probable if the respondent has had training, an apprenticeship or has passed any $\mathrm{O}$ levels and less likely if unemployment has occurred or he was unable or unwilling to report his first job earnings. Overall, the picture is one of data loss between 1958 and 1981 being associated with low parental social class, a poor training record, absence of educational qualifications and, not surprisingly, the inability of either the parents or the child to provide some of the requested data at either date. 8

\section{Table 1 about here}

We do not insert the estimated inverse Mills ratios based on Table 1 into all the 
regressions of occupational earnings. In fact it is only in the final specification which includes explanatory variables formed from information collected at age 23 that we enter the selection correction term. If entered in the equations containing only explanatory variables based on earlier sweeps of the panel, the selection terms might appear to be significant purely because the estimated inverse Mills ratios are in part functions of variables which we have yet to include. For example, a regression which aims to show the full effect of the family circumstances at birth would exclude the exam and training record which may have important independent effects on occupational success. If a selection term is included in this regression then we may get a biased estimate of its true impact solely because these latter factors are significant determinants of the probability of complete data, as we have seen.

We test for sample selection bias in the early regressions in a different way. Our strategy of progressively including different sets of variables means that with the exception of the final equation, we can test at each stage for differences in parameter estimates between the sample with complete data and the sample that has data up to and including that sweep, but for whom there are holes at later stages. For example, in the equations using only birth variables we can test for differences between the sample of 1,514 with complete data and the alternative sample provided by the remaining GB born early school-leavers still present in the panel at age 23, but with "holes" in the intervening period. All but 79 of these 2,339 individuals have an occupation at 23 coded to which we can attach the relevant New Earnings Survey figure. When we add information provided by the parents when the NCDS children were aged 16 , then the alternative sample with complete data up to that time falls to 1,244 (see the Data Appendix for further details). This is a substantial drop but we are still left with a large amount of data with which to test for any peculiarities in the sample of 1,514 individuals with no holes in the panel. Similarly, we can use data on those individuals with test scores recorded but for whom exam data are missing. These Chow tests of parameter stability are another way of establishing whether the missing data represent more of a problem than mere loss of efficiency. 
Finally, we exploit one further feature of the panel nature of the NCDS data. Not only do the data record occupation at 23 , but we also know the occupation of first job on entry to the labour force - seven years earlier in the case of 16 year old school leavers. We use this information to try and control for unobservable fixed effects that may be correlated with regressors. In particular we are interested in the observed work history variables which we use in our final specification, such as periods of training or apprenticeships. Again using information on average male hourly earnings from the 1981 NES, we estimate an equation in which the dependent variable is the difference in logs of the age 23 and 16 occupational earnings. Moreover, we can treat the expectations of the error terms in equations for these two occupational measures, conditional on complete data, as an unobservable fixed effect (assuming the unobservable influences on occupational earnings at the two ages are correlated in an identical fashion with those on data loss). Estimating the difference equation will therefore obviate the need to include any selection term in the regression, an advantage to the extent that our binary equation in Table 1 fails to adequately explain data loss. Table 2 gives some descriptive statistics on occupational hourly earnings at 16 and 23 in the complete data sample. The correlation between the two is 0.38 with 47 per cent of the sample rising up the occupational ladder during the seven years and 28 per cent falling. For the reader who may be curious we include in the table information on the actual hourly earnings at age 23. This falls short of occupational earnings at age 23 in four out of five cases but not surprisingly is more dispersed, the coefficient of variation being exactly double that for the occupational earnings.

Table 2 about here

\section{RESULTS}

\section{a) Birth Variables}

Table 3 shows the estimated impact of family background at birth on 
occupational earnings. The equation in column 1 is a restricted version of a more general equation in which all the relevant variables are included. The restrictions are imposed on the basis of the data in the sense that categories are amalgamated when their coefficients are very similar and are omitted when their impact is close to zero, a strategy that is applied throughout. ${ }^{9}$ The first point to note is that the degree of explanatory power is very low $\left(R^{2}=0.028\right)$. This is, to some extent, a result of the fact that our sample refers only to minimum age school leavers. As Micklewright (1989) makes clear, the role of family background is critical in determining whether or not boys stay on at school and this is, in its turn, a vital determinant of occupational success. Once we restrict ourselves to 16 year old school-leavers, it becomes far harder to explain the variation in the data because we cannot take advantage of the large gross correlation between length of schooling and occupational earnings.

\section{Table 3 about here}

Nevertheless, there are some small effects associated with both mothers' and fathers' social class and with mothers' educational attainment (but not fathers') and we can test whether these findings hold for all early male school-leavers still in the NCDS panel at age 23 with an occupation coded or whether they are peculiar to the sample of 1,514 individuals with complete data. The relevant $\mathrm{F}$ statistic is reported in the table and is just sufficient to reject the hypothesis of parameter stability at the 5 per cent level $\left(F^{c}\right.$ rit $\left.=2.21\right)$. However, inspection of the results for the alternative sample of 2,260 individuals showed that it was only with the coefficient on the mother's schooling dummy that there was any difference in the second decimal place. The complete data sample does not therefore appear to give results concerning the effect of birth variables that are misleading.

It is well worth noting the result of including at this stage for each individual the selection adjustment term calculated using the results of the "holes" in the panel logit of Table 1. When introduced in equation 1 in Table 3, the coefficient of this 
calculated variable has a t-ratio of over 7 , which could be interpreted as indicating very significant problems of sample selection with the use of the complete data sample. However, the results of the Chow test of parameter stability do not support such a firm conclusion which suggests that the significance of the selection term stems largely from our exclusion from the equations in Table 3 of important post-birth influences on occupational attainment which are strongly correlated with the variables used to calculate the selection term. This comparison of the two methods of detecting selection bias is evidence in support of our policy of including the selection term in our final specification only.

An important issue is the effect of ethnic group. We have far too few individuals from non-white ethnic groups to estimate separate equations as in the discrimination literature, but in column 2 we add to the equation a dummy variable indicating race. The results do not suggest a lower occupational attainment for nonwhites; indeed, the reverse is true, the coefficient indicating 8-9 per cent higher occupational earnings at 23 . The relevant coefficient is not well determined but it is interesting to note that the precision increases (with no fall in the size of the estimated effect) when test scores, exams and post-schooling variables are added to the specification. However, we do not retain the race dummy in our preferred specification since the results from the available alternative sample suggests that a significant association of non-white ethnic group and occupational success may be peculiar to the complete data sample. 10

Is parental social class background when the boys leave school at age 16 the key factor, or is it that at birth? It may be that what matters is the ability of parents to smooth the path of their sons into higher occupations via their ability to finance training and their social contacts rather than the provision of "resources", in the broadest sense of the word, from the earliest years of their son's lives. In equations 3 and 4, in Table 3 we add in the parents' social class at age 16; only if the father is in social class 1 or 2 do we find any significant additional effect, this being worth about 5 per cent on occupational earnings controlling for parental background at birth. 
Furthermore, the impact of parental background at birth is not substantially affected and we retain only the birth class variables in subsequent equations. We also include in equations 3 and 4 the eventual number of brothers and sisters when the family is presumably, more or less complete (that is, when the cohort was aged 16). We find (weak) evidence that siblings have a deleterious impact on the occupational success of early school leavers. The overall effect is, however, tiny, representing little more than a one-half per cent reduction in earnings for every sibling (this again is a result where the conditioning on school-leaving is important - see Micklewright, 1989).

\section{b) Attainment Test Scores}

The additional impact of the test scores is presented in Table 4. In order to capture the impact of the scores we have given ourselves a considerable degree of flexibility by using dummy variables which are associated with the quintiles of the score distribution for the early school leaver sample (or the thirds in one case) rather than using the score directly. ${ }^{11}$ As before, the equations presented are data based restrictions of more general models. Starting with equation 1 , we find that including variables summarising the test results at age 7 has a substantial effect. School leavers who are in the top third in the maths test and in the top 40 per cent on the reading test end up, on average, 9 per cent higher in terms of occupational earnings. When we include the test scores at age 11 , there is a further increase in the explanatory power of the regression and although the impact of the age 7 test is reduced, they do not become insignificant. Overall, the scores at age 11 appear slightly more important than those at age 7 but there is little to choose between them. Good scores in reading and maths at both ages will raise occupational earnings at age 23 by nearly 13 per cent. By contrast the general ability test does not appear to be very important.

\section{Table 4 about here}

Once we include the age 16 test scores most of the earlier results become 
insignificant although the age 7 maths result still carries some weight. However, if we drop the intermediate age results as in equation 4 , we can see more clearly just how important are these basic attainment measures at age 16 in determining occupational success. A school leaver who was in the top quintile in both maths and reading at age 16 could expect to have occupational earnings which are some 18 per cent higher than someone who was in the bottom quintile, with those in the middle three quintiles about half way between. Interestingly enough the effect of the inclusion of all these ability measures on the influence of the family background variables is not great in the sense that their coefficients are, in the main, only slightly smaller in Table 4 than they are in the first column of Table 3. (The only exception to this is the measure of mother's educational attainment which becomes completely unimportant but about which we voiced some doubt given the results of the regression run on the alternative data.) This pattern of results is, perhaps, a little surprising but it does imply that however it operates, class background does not appear to work, to any important extent, via its association with basic attainment, given that the individual leaves school at 16.12 The rather slight effect of siblings on occupational success of early school leavers does however disappear once we control for test scores at 16.

Finally, we note the results of estimating the equations in Table 4 using the alternative samples of those individuals with complete data up to this point but without the later exams data. The largest alternative sample is for the specification in column 1 , but even here we cannot reject the hypothesis of parameter stability.

\section{c) Age 16 Variables}

For the remainder of the paper we build on the parsimonious specification in equation 4 of Table 4 and in Table 5 we include a number of additional variables available at age 16, in particular those related to formal qualifications obtained prior to leaving-school. The possession of ' $\mathrm{O}$ ' level passes (or their equivalents) is of considerable importance particularly if the individual has three or more which leads to a rise of over 10 per cent in occupational earnings, an effect which is very well 
determined. On the other hand, the more common CSE passes (grade 2-5) appear to have a more modest impact (five or more CSEs leads to a rise of only 3 per cent). A comparison of Table 5 with Table 4 column 4 reveals that once ' $O$ ' level results are included, the impact of the age 16 test scores are reduced with the greatest change occurring to the coefficients of the top quintile dummies. However, the hypothesis that the test score variables have no significant effect is easily rejected and so basic attainment scores and the achievement of formal qualifications do have important independent effects.

\section{Table 5 about here}

The reasons underlying this result are obviously complex. The acquisition of 'O' level passes while at school - something achieved by a third of the sample reflects both a certain degree of factual knowledge and an ability to work with some diligence and organisation over a considerable period of time. So it represents factors other than basic attainment. Furthermore, 'O' level passes are utilised by employers both as formal and informal entry requirements to certain occupations in a world where basic attainment scores are not generally available unless the employers conduct their own tests (a situation which will presumably change when formal public tests of attainment during compulsory schooling are introduced in the 1990s). On the other hand, even in the absence of ' $O$ ' level passes, an individual with high attainment scores clearly possesses abilities which are valuable in the labour market and we might expect these abilities to be recognised as labour market experience accumulates. So it is not surprising that an individual with high attainment scores will achieve a considerably higher occupational ranking than one with lower scores even if he possesses no 'O' level qualifications on leaving school.

To summarise the numbers, we may consider one or two examples. An individual in the top quintile in both maths and reading tests at age 16 and with 3 or more 'O' level passes can be expected to obtain an occupational position which is 20 per cent higher than someone with no ' $\mathrm{O}$ ' levels and bottom quintile attainment test 
scores. Someone with 2 'O' levels and average test scores would be just above halfway between these two individuals in the occupational ranking. 13

If the individual comes from a poor background, as measured by free school meals receipt in the family in 1974, then he ends up 6 per cent down on the occupational ranking holding basic attainment scores and formal qualifications fixed, the relevant coefficient being reasonably well determined. It is interesting to compare this finding with the results obtained when a direct measure of normal household income is used in place of the free school meals dummy. The estimated coefficient of income is positive but is not very precise $(t=1.9)$ and is very small - a rise in income of two standard deviations being associated with an increase in occupational ranking of only about 3 per cent. While this comparison may suggest that entering income in levels is not appropriate it is also possible that to some extent the receipt of free school meals (which occurs in the families of 10 per cent of the sample) proxies a disadvantage other than lack of income. ${ }^{14}$

Living in one of the outer regions of Britain (excluding the South West and Wales but including the South) entails a small reduction in opportunities and finally in this equation it is worth noting that individuals who went to grammar or independent schools had no significant advantage. This possibly reflects the fact that rather few individuals leave such schools at age 16 and those that do are no more attractive to potential employers than the average 16 year old school leaver from a comprehensive school or secondary modern school. 15

\section{d) Age 23 Variables}

In column 1 of Table 6 we find that we can explain 20 per cent of the variation in occupational earnings once we include selected details of the individual's work history (we remind the reader of our earlier discussion about the need for caution when exploiting this information). The qualification variables do not overlap in the sense that it is the highest qualification attained that is coded. The measures of training have no natural ordering however and more than one dummy variable indicating that 
training has occurred may take the value one for an individual. An important question is whether qualifications have any independent effect given that we control for training and other aspects of employment history. In other words, is it only how "time was spent" which is important or do the qualifications gained have an additional impact? The results in the first column of Table 6 confirm the latter view and a F-test decisively rejected a restricted equation in which the post-16 qualifications were excluded. Moreover, the coefficients and standard errors of most of the training variables were little changed in the absence of the qualifications.

\section{Table 6 about here}

Completion of an apprenticeship, the commonest form of training for the male 16 year old leavers in the NCDS panel, has no discernible impact on occupational success nor does any attendance at a day/block release course which the apprenticeship may have entailed, this being the case whether we include qualification variables or not. An apprenticeship would most frequently lead to a City and Guilds qualification and, surprisingly, this also has no significant impact. On the other hand, those who attend some kind of vocational training course during a job attain a significantly higher occupational position despite the fact that nearly 20 per cent of them obtain no formal qualification as a result. Similarly, the residual group "Any Other Course" is also associated with a (not very well determined) small increment in occupational earnings despite there not necessarily being a qualification associated with the course nor, indeed, necessarily any labour market training given. ${ }^{16}$ The qualifications obtained after leaving school which appear of particular benefit are HNCs and the residual "other qualifications", both of which are associated with an 8-9 per cent rise in occupational earnings.

Besides measures of training and qualifications, we are also able to include other elements of employment experience. Job changing is of some importance, those who stick in one job end up around 7 per cent higher on the occupational ladder than 
the small minority with 7 or more, but on the other hand, they do not appear to do any better than the vast majority ( 80 per cent) with between 2 and 6 jobs. Slightly less than a third of the sample spent a total of three months or more in unemployment between 1976 and 1981. These individuals find themselves at age 23 over 4 per cent down in terms of occupational earnings.

Despite the inclusion of all these additional variables, the basic attainment measures and school leaving qualifications, while attenuated, retain an independent role. Thus, while they obviously influence the pattern of job history and further qualifications, they continue to have a large direct impact on occupational earnings. For example, we see that those with attainment test scores at age 16 in the top quintile have 6 per cent higher occupational earnings than those in the bottom quintile even when controlling for the relevant details of job history and further qualifications and training. Interestingly enough, the same applies to the impact of coming from a poor background as measured by free school meals receipt in the household when the individual was aged 16. It might be imagined that the impact of this on future occupational position, controlling for basic attainment scores and leaving qualifications, would have been via the acquisition of further training and qualifications or via instability of employment. This does not, however, appear to be the case since the coefficient on this variable is hardly affected when all these additional variables are included. Its impact is absolutely direct and stays with the individual irrespective of his important early labour market experiences. There is some weak evidence that the self-employed are ceteris paribus a little lower in the occupational ranking at age 23 . Note that the same may not be true for their place in the income distribution. Many self-employed may have modest occupations but have higher incomes than an employed person in the same occupation.

The equation in column 1 of Table 6 represents our final specification. We therefore attempt to allow for any sample selection bias through data loss by including as an additional explanatory variable the estimate of the inverse Mills ratio for each individual, calculated using the results of the logit of "holes" in the panel presented 
earlier in Table 1 . The coefficient of the selection term, $\lambda$, is quite insignificant. It is tempting to view this as implying that there is little need to adjust for potential selection-bias when using the complete data sample but the result may in part represent a failure to identify the selection effect given that the equations now contain some variables that were also used to calculate the $\lambda$ s (see Table 1).

\section{e) Occupational Change}

The second and third columns in Table 6 give results from estimating equations in which the dependent variable is the difference in logs of occupational earnings at 23 and occupational earnings in the first job at 16. This equation controls for unobservable fixed effects on earnings - including any selection effects - which may have led to bias in estimated coefficients in column 1 of Table 6 and in earlier tables. We present two sets of results, one in which the specification is identical to that in the first column of the table (with the exception of the selection term which now drops out) and one in which we force variables analysed in Tables 3-5 to have the same impact on occupational earnings at both 16 and 23 . In this latter equation, the only regressors are the variables which were added to the specification in Table 6 , describing events in the period since leaving school.

Looking first at the equation in column 2 , we see that some pre-entry variables are quite insignificant, indicating that their impact is the same at the two ages (although we cannot tell whether this impact was spurious and the result of correlation with an unobserved fixed effect). An example is the variable indicating a low income family as proxied by receipt of free school meals. However, other variables are significant and a F-test rejects the equation in column 3 in favour of that in column 2 at the $1 \%$ level. Some variables now appear to have an impact despite being insignificant in the earlier levels equations. An example is the variable indicating attendance at a grammar or private school. The small minority of early leavers who attended such schools appear to move down the occupational ranking between 16 and 23 by about 5 per cent although we should note that the effect is not very well determined. 
Of principal interest are the coefficients on the post-entry variables introduced in column 1 , these being time-varying characteristics in the analysis of occupational success. The rather imprecisely determined positive and negative effects of marriage and long-term ill-health or disability respectively are little changed from column 1 (the coefficient on the marital status dummy is interestingly exactly the same as that in the difference equation reported in Nickell, 1982, Table I). Several of the qualification variables have a very similar impact in the difference equations to their effect in the levels equation. This is not surprising since we know that certain higher-paying occupations require certain qualifications. Given that we control for ability with other measures, such as attainment scores, these qualifications are unlikely to represent unobserved ability. This applies to the post-entry O levels, "other qualifications", and (to a slightly lesser extent) to the possession of a Higher National Certificate. Note, however, that the vocational training variable is now quite insignificant suggesting that courses providing this sort of training as part of a job do not in fact raise an individual up the occupational ranking. The significance of this variable in column 1 of Table 6 appears to be due to the variable being correlated with some unobserved influence which has an independent effect on occupational success.

Finally, we note two rather different results relating to the employment history variables. The variable indicating seven or more jobs is completely insignificant in the difference equations. Its impact in the levels equation is, therefore, due to it proxying an individual attribute we have been unable to control for. In other words, the lower occupations of frequent job changers at age 23 is a result of characteristics such individuals bring to the labour market at age 16. On the other hand, the impact of three or more months of unemployment is even more marked in the difference equation. Individuals experiencing such unemployment suffer a drop down the occupational ladder of 7-8 per cent, the relevant coefficient being very well determined. This finding is similar to that of Nickell (1982) in a sample of all ages and schooling levels. 


\section{CONCLUSIONS}

The majority of children in Britain leave full-time education at 16 , the earliest legal opportunity. Despite the fact that they all have the same length of formal schooling, their subsequent occupational success varies a great deal. In this paper we have attempted to identify factors determining occupational success for the male half of this group using the very rich data available in the National Child Development Study. We have exploited the panel nature of the NCDS data by allowing for panel attrition (in two different ways) and by employing a fixed-effects estimator using information on occupation at age 16 in addition to that at 23 .

Family background at birth has a small but reasonably well defined impact on future success. Thus, for example, if both parents are in one of the top three social classes then we can expect occupational earnings at age 23 to be at least 7 per cent higher than if both parents are in the bottom social class, conditional on leaving school at 16. Furthermore, this effect does not appear to operate via educational attainment but through some other mechanism. Scores on tests of basic attainment and formal qualifications both have very important independent effects on occupational earnings and these are relatively large. Thus relative to being in the bottom quintile on the attainment tests at 16 and having no formal qualifications at this age, those in the top quintile having three or more ' $\mathrm{O}$ ' levels are, on average, 20 per cent higher in the occupational earnings league. It is worth emphasising yet again that all of these effects, even though they appear quite important, are only partial ones. Each of these variables also has a strong impact on the probability of staying on in full-time education beyond 16 years of age so their full effect will be larger than that reported here. Formal qualifications after leaving school are also important, and taken within the results on the effect of 'O' levels show that the concern for "certification" of skills in such programmes as the Youth Training Scheme (YTS) and the Technical and Vocational Educational Initiative (TVEI) may be well-founded. It is possible that their importance will diminish, however, when there is national formal testing of basic 
attainment during childhood under the terms of the 1988 Education Reform Act. We have seen that attainment tests are significant predictors of occupational success in the NCDS cohort. When the results of such tests are available to employers their impact may be even greater, at the expense of later formal qualifications.

Finally, we note again one of our most precisely determined results. Three or more months of unemployment during 1974-1981 is associated with a fall in the occupational ranking during this period of about 7 per cent, a result that was obtained while controlling for any unobserved fixed influence on occupational success which might be correlated with unemployment experience. 


\section{Data Appendix}

The basic sample used in the regressions in Tables 3-6 consists of 1,514 individuals taken from the National Child Development Study (NCDS). Table A1 shows how this sample was arrived at.

\section{Table A1 about here}

The potential sample of 3,853 excludes those individuals in NCDS4 who left school at 16 but who were not born in Britain and thus not present in the age zero sweep of the panel. The definition of leaving school at 16 is completion of full-time education by September 1974. Table A1 shows that 98 percent of the potential sample had the relevant occupational details recorded in 1981. Future users of NCDS should note that the questionnaire at age 23 makes it clear that if the first occupation has continued unchanged then "current or last" occupation will not be coded. This happens for a significant proportion of our potential sample and these individuals have been retained in our analysis with their "current or last" occupation recoded as that at 16. (Robertson and Symons (1990, p. 831) report some 22 percent of "current or last" occupations missing for all males present in NCDS4 but it is not clear whether allowance is made for the above coding convention.) The NCDS data are available from the ESRC Archive at the University of Essex; the panel is on-going and is managed by the Social Statistics Research Unit at City University, London, who can provide information on the latest sweep available for secondary analysis.

In order to match up occupations with hourly earnings, we used the information from the 1981 Department of Employment, New Earnings Survey, Occupational Table No. 86 augmented by some additional unpublished information supplied by the Department of Employment. The New Earnings Survey (NES) provides earnings broken down by some 150 occupations based on an aggregate version of the CODOT system. NCDS4 classifies individuals into some 340 
occupations and thus uses a somewhat more refined classification than the New Earnings Survey although still based on CODOT. In matching the two, if there was more than one NCDS occupation within any particular NES occupation they were simply given the same level of earnings. To obtain hourly earnings, we divided average weekly earnings by average weekly hours worked given in the same tables. Where weekly hours were not available, as with some non-manual occupations, we set weekly hours at 39 . SAS code to match occupations to average earnings and hours is available from the authors on request.

Table A2 about here 


\section{Footnotes}

1. According to the National Child Development Study, just over 60 per cent of boys born in March 3-9, 1958 had left full-time education by September 1974 having reached the age of sixteen in March of that year.

2. By "leaving school" we mean completing full-time education. Boys who left school but continued full-time education in a College of Further Education or a Tertiary College, for example, are thus omitted.

3. This is the approach used in Elias and Blanchflower (1988) and Robertson and Symons (1990), for example.

4. Atkinson et al document the importance of parents for securing entrance to apprenticeships for their sons. Osterman reports over $30 \%$ of a sample of 16 25 year olds who had left school with less than 12 years of education, having found their jobs through parents or other relatives (Table 3.1).

5. The total number of school leavers of all ages in Britain who joined the labour force in Summer 1973 was about half that in a normal year (DE Gazette, December 1975, p.1269). We cannot discount the possibility that the 1974 cohort of leavers may represent a special case with an average occupational success that differs from other cohorts.

6. An alternative cardinal measure of occupational success would be the HopeGoldthorpe scale. Nickell (1982) reports a correlation coefficient of 0.85 between this measure and log occcupational hourly earnings in a sample of men of working age.

7. This approach is similar to that of Griliches, Hall and Hausman (1978). It is true of course that we are conditioning on response to the NCDS panel at age 23. In other words, we do not model the loss of about one third of the panel between birth and age 23 . This is because it is only at the age 23 sweep that the school-leaving date is identified and it is the population of age 16 leavers that we are concerned with. (We cannot of course identify which of the early drop-outs from the panel were early leavers.) See National Childrens Bureau (1984) for further information on response to the age 23 sweep and Micklewright (1988) for a model of schooling choice that includes allowance 
for panel drop-outs as well as panel holes.

8. A large number of age 23 variables were tried in the data loss equation but proved insignificant. These included the level of first job earnings, health variables, and dummy variables indicating 6 or more jobs since leaving school, a father unemployed in 1981, trade union membership and home ownership.

9. Thus, for example, in Table 3 , column 1 , we originally included all the different social class categories for both parents as well as whether or not the father stayed on at school. These were then dropped or amalgamated to reveal what is present in the table.

10. The alternative sample is rather smaller than for the column 1 equation since information on ethnic group was collected in the medical questionnaire at age 16. Note that our samples relate to children born in Britain and exclude immigrants to the country after 1958 . (The NCDS has collected information on immigrants born in the relevant week but we have not included these individuals in our analysis).

11. The direct use of the score is inflexible in the sense that it asserts that each point added to the score has the same marginal effect on log occupational earnings. The present method allows some variation in the impact of additional marks depending on the initial position in the overall distribution. The banding is approximate because of the lumpiness in the scores. That is, if we take the top third on the age 7 maths score for example to be those who get 7 or more we get less than one third and if we take all those who score 6 or more we get more than one third.

12. It is worth re-emphasising at this point that we are conditioning on leaving school at 16. Class background is very important in determining whether or not individuals stay on in full time education with both direct effects at 16 as well as indirect effects via attainment (see Micklewright, 1989).

13. The results presented in Table 5 assume that test scores and ' $O$ ' level passes have additive effects. We investigated various possible interactions and as a result concluded that simple additivity gave the most accurate impression, the interaction effects being of little consequence. 
14. It is worth noting that household income when the child is 16 is not well measured in the NCDS. Moreover, it is collected in the form of discrete bands and we have taken the mid-points of these together with an extraneous estimate of the unbounded top range. (See Micklewright, 1986, for further details). The relevant information is missing for 1 in 5 of our 1,514 "complete data" sample and when entering income in levels we therefore entered a missing data dummy for these cases.

15. We also tested the effect of adding the male unemployment rate in the individuals travel-to-work-area in June 1974. Rather surprisingly, this had no discernible impact. (Nor did that in June 1981.) The same applies to a variable indicating unemployment before the first job although it should be noted that there was a buoyant labour market in 1974. We also investigated whether or not possession of a spare-time job when still at school had any impact and it appears to have no significant effect. The effect of earnings from such jobs on the leaving decision itself is discussed in Micklewright (1988). See Michael and Tuma (1984) for evidence on pre-16 work in the US.

16. The "Attended Vocational Training" variable refers to courses taken during a job but the training need not necessarily have occurred at the place of employment although this did happen in some 40 per cent of cases (the training was College-based in most other instances). The "Any Other Course" variable refers to courses not taken as part of a job. 


\section{References}

Atkinson, A.B., Maynard, A.B. and Trinder, C.G. (1983), Parents and Children, London: Heinemann.

Blau, P.M. and Duncan, O.D. (1967), The American Occupational Structure, New York: Wiley.

Elias, P. and Blanchflower, D. (1988), "Occupational Earnings and Work Histories:

Who Gets the Good Jobs?" Institute of Employment Research, Warwick University.

Fogelman, K.R. (ed) (1983), Growing Up in Great Britain: Collected Papers from the National Child Development Study. London: Macmillan.

Griliches, Z., Hall, B.H. and Hausman, J.A. (1978), "Missing Data and SelfSelection in Large Panels", Annales de L'INSEE, No. 30-31, pp.137-176.

Heath, A. (1981), Social Mobility, London: Fontana.

Heckman, J. (1979), "Sample Selection Bias as a Specification Error", Econometrica, Vol. 47, pp. 153-161.

Lee, L.F. (1983), "Generalised Econometric Models with Selectivity", Econometrica, Vol. 51, pp.507-12.

Marin, A. and Psacharopoulos, G. (1982), "The Reward for Risk in the Labour Market: Evidence from the UK and Reconciliation with Other Studies", Journal of Political Economy, August. 
Michael, R.T., and Tuma, N. (1984), "Youth Employment: Does Life Begin at 16?", Journal of Labor Economics, Vol. 2, No. 4, pp. 464-476.

Micklewright, J. (1986), "A Note on Household Income Data in NCDS3", NCDS User Support Group Working Paper 18, Social Statistics Research Unit, The City University.

Micklewright, J. (1988), "Schooling Choice, Educational Maintenance Allowances and Panel Attrition", Queen Mary and Westfield College, University of London, Department of Economics Discussion Paper 185.

Micklewright, J. (1989), "Choice at Sixteen", Economica, Vol. 56, pp. 25-40.

National Children's Bureau (1984), "National Child Development Study (1958 Cohort) Fourth Follow-up: Final Report to Sponsors", NCB.

Nickell, S.J. (1982), "The Determinants of Occupational Success in Great Britain", Review of Economic Studies, Vol. 49, pp. 43-53.

Osterman, P. (1980), Getting Started, Boston: MIT.

Robertson D. and Symons J. (1990), "The Occupational Choice of British Children," Economic Journal, Vol. 100, pp. 828-841. 
Table 1

Logit Estimation of Probability of Complete Data $\mathrm{N}=3,853$ (1,514 with complete data)

Independent Variables

Coefficient $t$-statistic

Constant

$-0.694$

0.102

Mother stayed on at school (post minimum leaving age)

0.360

(1.0)

Father in Social Class 1 or 2 at respondent's birth

0.282

Father in Social Class 3 at respondent's birth

Father in Social Class 4 at respondent's birth

0.355

(2.9)

Mother could not provide information on her Father's Social Class

$-0.308$

Born in North West

$-0.265$

(2.3)

Born in the Midlands

$-0.166$

(1.4)

$-0.126$

Born in the East

0.352

Born in London or the South-East

$-0.476$

Born in Scotland

0.315

Completed an apprenticeship

0.178

$$
\text { (2.4) }
$$

0.138

(1.8)

Attended training course at least 14 days or 100 hours long

$-0.225$

Passed at least one $\mathrm{O}$ level (or equivalent) at any time

0.301

Problems with writing or spelling since leaving school

$-0.106$

$-0.273$

Divorced or Separated at 23

$-0.331$

No reported 1st job wage

$-0.646$

$\log$ likelihood

log likelihood with optimal constant

Note: $\quad$ The complete data sample is defined in detail in the Data Appendix which gives the different reasons for data loss among the 3,853 cases in NCDS 4 which form the potential sample. 
Table 2

\section{Gross Earnings: \&s per hour 1981}

$\begin{array}{lcc} & \text { Mean } & \begin{array}{c}\text { Standard } \\ \text { Deviation }\end{array} \\ \text { Occupational Earnings aged 16 } & 3.12 & 0.53 \\ \text { Occupational Earnings aged 23 } & 3.33 & 0.68 \\ \text { Actual Earnings aged 23 } & 2.60 & 1.05\end{array}$

Notes: 1) The statistics on occupational earnings refer to the 1,514 individuals in the "complete data" sample. The information on actual gross earnings at 23 relates to the current job if employed and last job if not. This information is only present for 1,305 individuals, (being missing or a net figure in remaining cases) and the statistics refer to this sub-sample.

2) Occupational earnings at both 16 and 23 are based on the 1981 New Earnings Survey. 
Table 3

Occupational Earnings at age 23 explained using Birth Variables

Dependent Variable: Log (Occupational Earnings 1981)

Independent Variables

Constant

Mother stayed on at school (post minimum leaving age)

Mother in social class 1 or 2 at respondent's birth

Mother in social class 3 at respondent's birth

Father in social class 1,2 or 3 at respondent's birth

Respondent is non-white

Number of siblings when respondent is aged 16

Mother not working when respondent is aged 16

Mother in social class 1 or 2 when respondent is aged 16

Mother in social class 3 when respondent is aged 16

Mother in social class 4 when respondent is aged 16

Father unemployed when respondent is aged 16

Father in social class 1 or 2 when respondent is aged 16

Father in social class 3 when respondent is aged 16

Father in social class 4 when respondent is aged 16

$\mathrm{R}^{2}$

Standard Error

$\mathrm{F}$
1

1.136

$0.032(2.3)$

0.084 (2.6)

$0.038(3.2) \quad 0.038(3.2) \quad 0.027(2.2)$

$0.043(4.0) \quad 0.044(4.0)$

$0.085(1.9)$

3

1.148

1.135

0.022 (1.6)
1.156

$0.025(1.8)$

$0.075(2.3)$

$0.032(2.6)$

$0.029(2.5) \quad 0.035(3.2)$

$-0.005(1.8) \quad-0.007(2.5)$

$-0.028(1.6)$

$0.006(0.3)$

$0.012(0.7)$

$-0.010(0.5)$

$0.007(0.4)$

$0.061(3.0) \quad 0.042(2.9)$

$0.023(1.5)$

$0.008(0.4)$

$\begin{array}{cl}0.028 & 0.030 \\ 0.192 & 0.191 \\ \mathrm{~F}_{376 \overline{4}}^{5}-2.30 & \mathrm{~F}_{2746}^{6}=2.30\end{array}$

0.045

0.037

$0.190 \quad 0.191$

$\mathrm{F}_{2418}^{14}=0.79 \quad \mathrm{~F}_{2418}^{7}=0.95$

Note: 1) t t statistics are in parentheses.

2) F statistics refer to Chow tests of parameter stability over complete data and alternative sample. 
Table 4

Occupational Earnings at age 23: the Role of Test Scores

Dependent Variable: Log (Occupational Earnings 1981)

Independent Variables

Constant

Mother stayed on at school (post minimum leaving age)

Mother in social class 1 or 2 at respondent's birth

Mother in social class 3 at respondent's birth

Father in social class 1,2 or 3 at respondent's birth

Number of siblings when respondent is aged 16

In top third, maths test, age 7

In top two quintiles, reading test, age 7

In third, fourth quintiles, maths test, age 11

In top two quintiles, maths test, age 11

In top quintile, reading test, age 11

In third, fourth quintile, general aptitude test, age 11

In top two quintiles, general aptitude test, age 11

In second, third or fourth quintile, maths test, age 16

In top quintile, maths test, age 16

In second, third or fourth quintile, reading test, age 16

In top quintile, reading test, age 16

$\mathrm{R}^{2}$

Standard Error

F

Note:
1

1.120

$0.026(1.9)$

$0.079(2.5)$

$0.032(2.8)$

$0.037(3.4)$

$\begin{array}{llll}-0.005(2.0) & -0.003(1.2) & -0.002(0.7) & -0.002(0.8)\end{array}$ $0.042(4.0) \quad 0.026(2.4) \quad 0.022(2.1)$

$0.047(4.5) \quad 0.025(2.2) \quad 0.019(1.7)$

$0.033(2.1) \quad 0.020(1.2)$

$0.045(2.4) \quad 0.022(1.1)$

$0.028(2.1) \quad 0.011(0.7)$

$0.017(1.1) \quad 0.002(0.1)$

$0.032(1.7) \quad 0.007(0.3)$

$0.051(3.9) \quad 0.059(4.5)$

$0.076(4.0) \quad 0.098(5.6)$

$0.022(1.4) \quad 0.042(3.1)$

$0.046(2.3) \quad 0.079(4.8)$

$\begin{array}{llll}0.065 & 0.082 & 0.099 & 0.090\end{array}$

0.188

0.187

0.185

0.186

$\mathrm{F}_{2223}^{8}=0.89 \quad \mathrm{~F}_{202 \sigma}^{13}=1.57 \quad \mathrm{~F}_{168 \sigma}^{17}=1.03 \quad \mathrm{~F}_{200 \mathrm{~F}}^{10}=1.06$

$F_{2223}^{8}=0.89 \quad F_{202 \sigma}^{13}=1.57 \quad F_{168 \bar{\sigma}}^{17.03} \quad F_{200 \%}^{10}=1.06$

1) t statistics are in parentheses.

2) F statistics refer to Chow tests of parameter stability over complete data and alternative sample. 
Table 5

Occupational Earnings at 23: the Role of Age 16 Variables

Dependent Variable: Log (Occupational Earnings 1981)

Independent Variable

Constant

1.065

Mother stayed on at school (post minimum leaving age)

$0.009(0.7)$

Mother in social class 1 or 2 at respondent's birth

Mother in social class 3 at respondent's birth

$0.072(2.4)$

Father in social class 1,2 or 3 at respondent's birth

Number of siblings when respondent is aged 16

$0.024(2.0)$

$0.025(2.4)$

$0.003(1.1)$

In second, third or fourth quintile, maths test, age 16

$0.048(3.6)$

In top quintile, maths test, age 16

$0.045(2.3)$

In second, third or fourth quintile, reading test, age 16

$0.030(2.3)$

In top quintile, reading test, age 16

$0.051(3.1)$

Went to grammar school or independent school

$-0.012(0.5)$

A child in the family receives free school meals in 1974

$-0.060(3.6)$

One or two 'O' levels at age 16

Three or more 'O' levels at age 16

$0.039(3.0)$

$0.110(6.4)$

$0.017(1.3)$

$0.032(2.6)$

Five or more CSEs at age 16 grades $2-5$

$-0.029(3.0)$

$\mathrm{R}^{2}$

0.131

Standard Error

0.182

Note: $\quad \mathrm{t}$ statistics are in parentheses. 
Table 6

Occupational Earnings at 23: the Role of Age 23 Variables

Dependent Variable:

Column 1 natural log (Occupational Earnings 1981)

Column 2-3 natural log (Occupational Earnings 1981/Occupational Earnings 1974)

Independent

123

Constant

$1.114-0.000$

0.055

Mother stayed on at school post minimum leaving age)

Mother in social class 1 or 2 at respondent's birth

Mother in social class 3 at respondent's birth

Father in social class 1,2 or 3 at respondent's birth

Number of siblings when respondent is aged 16

In second, third or fourth quintile, maths test, age 16

In top quintile, maths test, age 16

In second, third or fourth quintile, reading test, age 16

In top quintile, reading test, age 16

One or two 'O' levels at age 16

Three or more ' $\mathrm{O}$ ' levels at age 16

Three or four CSEs at age 16 grades 2-5

Five or more CSEs at age 16 grades 2-5

Went to grammar school or independent school

A child in the family receives free school meals in 1974

'Outer region', (North, North-West, East, South, Scotland)

On apprenticeship at age 23

Completed apprenticeship

Day or Block Release Course

Attended vocational training course as part of a job

Any other course

$0.011(0.8) \quad 0.007(0.5)$

$0.053(1.8) \quad 0.060(1.8)$

$0.023(2.0) \quad 0.004(0.4)$

$0.020(1.9) \quad 0.033(2.9)$

0.004 (1.5) $\quad 0.005(1.6)$

$0.037(2.9) \quad 0.030(2.2)$

$0.022(1.1) \quad 0.004(0.2)$

$0.018(1.3) \quad-0.006(0.4)$

$0.036(2.2) \quad 0.028(1.5)$

$0.031(2.4) \quad 0.023(1.7)$

$0.082(4.6) \quad 0.037(1.9)$

$0.016(1.3) \quad-0.003(0.2)$

$0.025(2.1) \quad 0.012(0.9)$

$0.005(0.2) \quad-0.048(1.9)$

$-0.057(3.6) \quad-0.021(1.2)$

$-0.025(2.7) \quad-0.016(1.5)$

$-0.215(1.7) \quad-0.200(1.4)$

$-0.007(0.3) \quad-0.043(1.5)$

$-0.174(1.3)$

$-0.006(0.2)$

$0.043(3.8) \quad-0.003(0.3) \quad 0.003(0.3)$

$0.027(1.9) \quad 0.023(1.5) \quad 0.036(2.3)$

$0.145(2.1) \quad-0.157(2.1) \quad-0.140(1.9)$

Higher National Certificate and similar qualifications

2 or more A levels

City and Guilds or $1 \mathrm{~A}$ level

At least 10 level obtained since school

Commercial or clerical qualifications

Other qualifications

Had between 2 and 6 jobs during the period 1974-81

Had 7 or more jobs in this period

Had 3 or more months of unemployment during the period 1974-81

Self employed at age 23

Married at age 23

Spent time out of the labour force due to ill-health or disability during 1974-81

$\lambda$ (correction term)

$0.079(3.3) \quad 0.058(2.2) \quad 0.080(3.1)$

$\begin{array}{lll}0.058(0.9) & 0.050(0.7) \quad 0.058(0.8)\end{array}$

$\begin{array}{lll}0.005(0.4) & 0.003(0.2) & 0.015(0.9)\end{array}$

$\begin{array}{lll}0.026(1.5) & 0.035(1.8) & 0.038(2.0)\end{array}$

$0.061(2.1) \quad 0.087(2.7) \quad 0.099(3.1)$

$0.084(2.5) \quad 0.099(2.7) \quad 0.099(2.7)$

$\begin{array}{lll}-0.014(1.2) & 0.034(2.8) & 0.033(2.8)\end{array}$

$\begin{array}{lll}-0.071(3.4) & 0.008(0.3) & 0.009(0.3)\end{array}$

$-0.044(3.9) \quad-0.073(6.2) \quad-0.079(6.8)$

$-0.035(1.6) \quad-0.041(1.7) \quad-0.040(1.6)$

$0.019(2.0) \quad 0.019(1.9) \quad 0.016(1.6)$

$-0.050(1.7) \quad-0.054(1.7) \quad-0.056(1.7)$

$-0.025(0.7)$

$\begin{array}{lll}0.199 & 0.104 & 0.078 \\ 0.180 & 0.193 & 0.195\end{array}$

$\mathrm{R}^{2}$

0.180

0.193

0.195

Note: $\quad t$ statistics in parentheses. 
Table A1: Definition of Sample

1. Number of males who were born in Britain in 1958, left school at 16 and who were interviewed in NCDS4 in 1981:

2. Number of these with first and current or last occupation coded in 1981 (see discussion below):

3. Number of these present in NCDS3 in 1974 with medical data: 2,758

4. Number of these present in NCDS3 in 1974 with parental data:

5. Number of these with test score data at 7,11 and 16:

6. Number of these with O level and CSE (or SCE exam records): 
Table A2 :

\section{Explanatory Variables in Complete Data Logit}

\section{Definition}

Mother stayed on at school (post minimum leaving age)

Father in Social Class 1 or 2 at respondent's birth

Father in Social Class 3 at respondent's birth

Father in Social Class 4 at respondent's birth

Mother could not provide information on her Father's Social Class

Born in North West

Born in the Midlands

Born in the East

Born in the South-West

Born in London or the South-East

Born in Scotland

Completed an apprenticeship

Attended training course at least 14 days or 100 hours long

6 months or more unemployment since leaving school

Passed at least one $\mathrm{O}$ level (or equivalent) at any time

Problems with writing or spelling since leaving school

Local Authority tenant at 23

Divorced or Separated at 23

No reported 1st job wage $\begin{array}{cc}\text { Mean } & \text { NCDS } \\ \text { Data Used }\end{array}$

0.145

0.085

0.603

0.142

0.086

0.121

0.110

0.077

0.057

0.156

0.111

0.377

0.289

0.249

0.383

0.161

0.153

0.032

0.031
N537(0)

$\mathrm{N} 236(0)$

$\mathrm{N} 236(0)$

$\mathrm{N} 236(0)$

N526(0)

N624(0)

$\mathrm{N} 624(0)$

N624(0)

N624(0)

N624(0)

N624(0)

N4439(4)

N4453, N4454(4)

UNEMTIME(4)

N4655(4)

N4660(4)

N5333, N5375(4

N5113(4)

N4223PW(4)

Note: The digit in brackets in the final column indicates the sweep at which the data were collected $(0=$ at birth, $1-4$ correspond to NCDS $1-4$ at ages $7,11,16$ and 23$)$. 


\section{Table A3 Explanatory Variables in Regressions}

\section{Definition}

Mother stayed on at school (post minimum leaving age)

Mother in social class 1 or 2 at respondent's birth

Mother in social class 3 at respondent's birth

Father in social class 1,2 or 3 at respondent's birth

Respondent is non-white

Number of siblings when respondent is aged 16

Mother not working when respondent is aged 16

Mother in social class 1 or 2 when respondent is aged 16

Mother in social class 3 when respondent is aged 16

Mother in social class 4 when respondent is aged 16

Father unemployed when respondent is aged 16

Father in social class 1 or 2 when respondent is aged 16

Father in social class 3 when respondent is aged 16

Father in social class 4 when respondent is aged 16

In top third, maths test, age 7

In top two quintiles, reading test, age 7

In third, fourth quintiles, maths test, age 11

In top two quintiles, maths test, age 11

In top quintile, reading test, age 11

In a third, fourth quintile, general aptitude test, age 11

In top two quintiles, general aptitude test, age 11

In second, third or fourth quintile, maths test, age 16

In top quintile, maths test, age 16

In second, third or fourth quintile, reading test, age 16

In top quintile, reading test, age 16

One or two 'O' levels at age 16

Three or more 'O' levels at age 16

Three or four CSEs at age 16 grades 2-5

Five or more CSEs at age 16 grades 2-5

Outer region, (North, North-West, East, South, Scotland)

Went to grammar school or independent school

A child in the family receives free school meals in 1974

Completed apprenticeship

On apprenticeship at age 23

Day or Block Release Course

Attended vocational training course as part of a job

Any other course

Degree

Higher National Certificate and similar qualifications

2 or more A levels

City and Guilds or $1 \mathrm{~A}$ level

Commercial or clerical qualifications

At least $1 \mathrm{O}$ level obtained since school

Other qualifications

Had between 2 and 6 jobs during the period 1974-81
Mean

0.158

0.025

0.220

0.713

0.013

2.505

0.318

0.076

0.253

0.242

0.065

0.139

0.565

0.169

0.384

0.421

0.428

0.404

0.190

0.406

0.412

0.627

0.174

0.561

0.241

0.191

0.144

0.187

0.279

0.466

0.050

0.102

0.427

0.001

0.392

0.314

0.140

0.005

0.063

0.005

0.390

0.029

0.085

0.021

0.673
NCDS

Data Used

N537(0)

N539(0)

N539(0)

N236(0)

N2017(3)

N2367, N2368,

N2369, N2370(3)

N2392(3)

N2393(3)

N2393(3)

N2393(3)

N2383(3)

N2384(3)

N2384(3)

N2384(3)

N90(1)

N92(1)

N926(2)

N926(2)

N923(2)

N920(2)

N920(2)

N2930(3)

N2930(3)

N2928(3)

N2928(3)

E234, E238(4)

E234, E238(4)

E246, E250,

E254, E258(4)

E246, E250,

E254, E258(4)

N2703(3)

N2102, N2103(3)

N2440(3)

N4439(4)

N4439(4)

N4450(4)

N4453,N4454(4)

N4526,N4527(4)

NEWGHSQ(4)

NEWGHSQ(4)

NEWGHSQ(4)

NEWGHSQ(4)

NEWGHSQ(4)

E234, E238,

N4656,NEWGHSQ(4)

NEWGHSQ(4)

N4144(4) 
Definition

Had 7 or more jobs in this period

Had 3 or more months of unemployment during the period 1974-81

Self employed at age 23

Married at age 23

Spent time out of the labour force due to ill-health or disability during 1974-81
NCDS

Mean

Data Used

0.070

0.303

N4144(4)

UNEMTIME(4)

0.044

0.476

0.024

N4321(4)

N5113(4)

N4827, N4836,

N4845, N4854(4)

Note: 1) The digit in brackets in the final column indicates the sweep at which the data were collected $(0=$ at birth, $1-4$ correspond to NCDS $1-4$ at ages $7,11,16$ and 23).

2) The social classes are 1: professional and managerial, 2: intermediate non-manual, 3: skilled, manual and non-manual, 4: semi-skilled, 5: unskilled manual and non-manual.

3) The test variable dummies represent approximate quintiles only due to the finite number of possible scores in any test. See footnote 11.

4) 'O' levels include CSE grade 1 and Scottish $O$ grades.

5) The qualification variables defined using only variable NEWGHSQ refer to "highest qualification". 


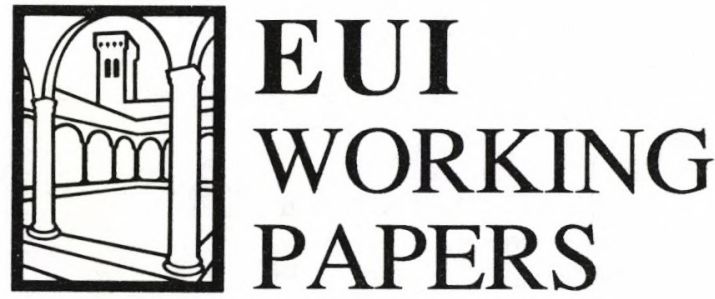

EUI Working Papers are published and distributed by the European University Institute, Florence

Copies can be obtained free of charge - depending on the availability of stocks - from:

The Publications Officer

European University Institute

Badia Fiesolana

I-50016 San Domenico di Fiesole (FI)

Italy

Please use order form overleaf 


\section{Publications of the European University Institute}

To The Publications Officer

European University Institute

Badia Fiesolana

I-50016 San Domenico di Fiesole (FI)

Italy

From Name

Address

$\square$ Please send me a complete list of EUI Working Papers

$\square$ Please send me a complete list of EUI book publications

$\square$ Please send me the EUI brochure Academic Year 1992/93

Please send me the following EUI Working Paper(s):

No, Author

Title:

No, Author

Title:

No, Author

Title:

No, Author

Title:

Date

Signature 


\section{Working Papers of the Department of Economics Published since 1989}

$89 / 370$

B. BENSAID/ R.J. GARY-BOBO/

S. FEDERBUSCH

The Strategic Aspects of Profit Sharing in the Industry

\section{$89 / 374$}

Francisco S. TORRES

Small Countries and Exogenous Policy Shocks

\section{$89 / 375$}

Renzo DAVIDDI

Rouble Convertibility: A Realistic Target

\section{9/377}

Elettra AGLIARDI

On the Robustness of Contestability Theory

\section{$89 / 378$}

Stephen MARTIN

The Welfare Consequences of Transaction Costs in Financial Markets

\section{$89 / 381$}

Susan SENIOR NELLO

Recent Developments in Relations Between the EC and Eastern Europe

\section{$89 / 382$}

Jean GABSZEWICZ/ Paolo GARELLA/

Charles NOLLET

Spatial Price Competition With Uninformed Buyers

\section{$89 / 383$}

Benedetto GUI

Beneficiary and Dominant Roles in

Organizations: The Case of Nonprofits

\section{$89 / 384$}

Agustín MARAVALL/ Daniel PEÑA

Missing Observations, Additive Outliers and Inverse Autocorrelation Function

\section{$89 / 385$}

Stephen MARTIN

Product Differentiation and Market Performance in Oligopoly

\section{9/386}

\section{Dalia MARIN}

Is the Export-Led Growth Hypothesis Valid for Industrialized Countries?
89/387

Stephen MARTIN

Modeling Oligopolistic Interaction

\section{$89 / 388$}

Jean-Claude CHOURAQUI

The Conduct of Monetary Policy: What have we Learned From Recent Experience

$89 / 390$

Corrado BENASSI

Imperfect Information and Financial Markets: A General Equilibrium Model

$89 / 394$

Serge-Christophe KOLM

Adequacy, Equity and Fundamental Dominance: Unanimous and Comparable Allocations in Rational Social Choice, with Applications to Marriage and Wages

$89 / 395$

Daniel HEYMANN/ Axel LEIJONHUFVUD

On the Use of Currency Reform in Inflation Stabilization

\section{$89 / 400$}

Robert J. GARY-BOBO

On the Existence of Equilibrium Configurations in a Class of Asymmetric Market Entry Games *

$89 / 402$

Stephen MARTIN

Direct Foreign Investment in The United States

\section{$89 / 413$}

Francisco S. TORRES

Portugal, the EMS and 1992: Stabilization and Liberalization

\section{$89 / 416$}

Joerg MAYER

Reserve Switches and Exchange-Rate Variability: The Presumed Inherent Instability of the Multiple Reserve-Currency System

\section{$89 / 417$}

José P. ESPERANÇA/ Neil KAY

Foreign Direct Investment and Competition in the Advertising Sector: The Italian Case

\footnotetext{
* Working Paper out of print
} 
$89 / 418$

Luigi BRIGHI/ Mario FORNI

Aggregation Across Agents in Demand Systems

$89 / 420$

Corrado BENASSI

A Competitive Model of Credit Intermediation

$89 / 422$

Marcus MILLER/ Mark SALMON

When does Coordination pay?

$89 / 423$

Marcus MILLER/ Mark SALMON/

Alan SUTHERLAND

Time Consistency, Discounting and the Returns to Cooperation

$89 / 424$

Frank CRITCHLEY/ Paul MARRIOTT/

Mark SALMON

On the Differential Geometry of the Wald Test with Nonlinear Restrictions

\section{$89 / 425$}

Peter J. HAMMOND

On the Impossibility of Perfect Capital Markets

$89 / 426$

Peter J. HAMMOND

Perfected Option Markets in Economies with

Adverse Selection

\section{$89 / 427$}

Peter J. HAMMOND

Irreducibility, Resource Relatedness, and Survival with Individual Non-Convexities

$$
\text { *** }
$$

ECO No. 90/1"

Tamer BASAR and Mark SALMON

Credibility and the Value of Information

Transmission in a Model of Monetary Policy and Inflation

ECO No. 90/2

Horst UNGERER

The EMS - The First Ten Years

Policies - Developments - Evolution

ECO No. 90/3

Peter J. HAMMOND

Interpersonal Comparisons of Utility: Why and how they are and should be made
ECO No. 90/4

Peter J. HAMMOND

A Revelation Principle for (Boundedly) Bayesian Rationalizable Strategies

ECO No. 90/5

Peter J. HAMMOND

Independence of Irrelevant Interpersonal

Comparisons

ECO No. $90 / 6$

Hal R. VARIAN

A Solution to the Problem of Externalities and Public Goods when Agents are Well-Informed

ECO No. 90/7

Hal R. VARIAN

Sequential Provision of Public Goods

ECO No. $90 / 8$

T. BRIANZA, L. PHLIPS and J.F. RICHARD

Futures Markets, Speculation and Monopoly

Pricing

ECO No. $90 / 9$

Anthony B. ATKINSON/ John

MICKLEWRIGHT

Unemployment Compensation and Labour

Market Transition: A Critical Review

ECO No. $90 / 10$

Peter J. HAMMOND

The Role of Information in Economics

ECO No. 90/11

Nicos M. CHRISTODOULAKIS

Debt Dynamics in a Small Open Economy

ECO No. $90 / 12$

Stephen C. SMITH

On the Economic Rationale for Codetermination Law

ECO No. 90/13

Elettra AGLIARDI

Learning by Doing and Market Structures

ECO No. 90/14

Peter J. HAMMOND

Intertemporal Objectives

ECO No. 90/15

Andrew EVANS/Stephen MARTIN

Socially Acceptable Distortion of Competition: EC Policy on State Aid

** Please note: As from January 1990, the EUI Working Papers Series is divided into six sub-series, each series will be numbered individually (e.g. EUI Working Paper LAW No. 90/1). 
ECO No. 90/16

Stephen MARTIN

Fringe Size and Cartel Stability

ECO No. 90/17

John MICKLEWRIGHT

Why Do Less Than a Quarter of the

Unemployed in Britain Receive Unemployment

Insurance?

ECO No. $90 / 18$

Mrudula A. PATEL

Optimal Life Cycle Saving

With Borrowing Constraints:

A Graphical Solution

ECO No. 90/19

Peter J. HAMMOND

Money Metric Measures of Individual and Social

Welfare Allowing for Environmental

Externalities

ECO No. $90 / 20$

Louis PHLIPS/

Ronald M. HARSTAD

Oligopolistic Manipulation of Spot Markets and the Timing of Futures Market Speculation

ECO No. 90/21

Christian DUSTMANN

Earnings Adjustment of Temporary Migrants

ECO No. 90/22

John MICKLEWRIGHT

The Reform of Unemployment Compensation:

Choices for East and West

ECO No. $90 / 23$

Joerg MAYER

U. S. Dollar and Deutschmark as Reserve Assets

ECO No. $90 / 24$

Sheila MARNIE

Labour Market Reform in the USSR:

Fact or Fiction?

ECO No. $90 / 25$

Peter JENSEN/

Niels WESTERGÅRD-NIELSEN

Temporary Layoffs and the Duration of

Unemployment: An Empirical Analysis

ECO No. 90/26

Stephan L. KALB

Market-Led Approaches to European Monetary

Union in the Light of a Legal Restrictions

Theory of Money
ECO No. 90/27

Robert J. WALDMANN

Implausible Results or Implausible Data?

Anomalies in the Construction of Value Added

Data and Implications for Estimates of Price-

Cost Markups

ECO No. $90 / 28$

Stephen MARTIN

Periodic Model Changes in Oligopoly

ECO No. $90 / 29$

Nicos CHRISTODOULAKIS/

Martin WEALE

Imperfect Competition in an Open Economy

$$
\text { ** } *
$$

ECO No. $91 / 30$

Steve ALPERN/Dennis J. SNOWER

Unemployment Through 'Learning From

Experience'

ECO No. 91/31

David M. PRESCOTT/Thanasis STENGOS

Testing for Forecastible Nonlinear Dependence in Weekly Gold Rates of Return

ECO No. 91/32

Peter J. HAMMOND

Harsanyi's Utilitarian Theorem:

A Simpler Proof and Some Ethical

Connotations

ECO No. $91 / 33$

Anthony B. ATKINSON/

John MICKLEWRIGHT

Economic Transformation in Eastern Europe and the Distribution of Income

ECO No. $91 / 34$

Svend ALBAEK

On Nash and Stackelberg Equilibria when Costs are Private Information

ECO No. 91/35

Stephen MARTIN

Private and Social Incentives

to Form R \& D Joint Ventures

ECO No. $91 / 36$

Louis PHLIPS

Manipulation of Crude Oil Futures

ECO No. 91/37

Xavier CALSAMIGLIA/Alan KIRMAN

A Unique Informationally Efficient and

Decentralized Mechanism With Fair Outcomes 
ECO No. $91 / 38$

George S. ALOGOSKOUFIS/

Thanasis STENGOS

Testing for Nonlinear Dynamics in Historical

Unemployment Series

ECO No. 91/39

Peter J. HAMMOND

The Moral Status of Profits and Other Rewards:

A Perspective From Modern Welfare Economics

ECO No. 91/40

Vincent BROUSSEAU/Alan KIRMAN

The Dynamics of Learning

in Mis-Specified Models

ECO No. 91/41

Robert James WALDMANN

Assessing the Relative Sizes of Industry- and

Nation Specific Shocks to Output

ECO No. 91/42

Thorsten HENS/Alan KIRMAN/Louis PHLIPS

Exchange Rates and Oligopoly

ECO No. 91/43

Peter J. HAMMOND

Consequentialist Decision Theory and

Utilitarian Ethics

ECO No. 91/44

Stephen MARTIN

Endogenous Firm Efficiency in a Cournot

Principal-Agent Model

ECO No. $91 / 45$

Svend ALBAEK

Upstream or Downstream Information Sharing?

ECO No. $91 / 46$

Thomas H. McCURDY/

Thanasis STENGOS

A Comparison of Risk-Premium Forecasts

Implied by Parametric Versus Nonparametric

Conditional Mean Estimators

ECO No. 91/47

Christian DUSTMANN

Temporary Migration and the Investment into

Human Capital

ECO No. $91 / 48$

Jean-Daniel GUIGOU

Should Bankruptcy Proceedings be Initiated by a Mixed Creditor/Shareholder?

ECO No. 91/49

Nick VRIEND

Market-Making and Decentralized Trade
ECO No. 91/50

Jeffrey L. COLES/Peter J. HAMMOND

Walrasian Equilibrium without Survival:

Existence, Efficiency, and Remedial Policy

ECO No. 91/51

Frank CRITCHLEY/Paul MARRIOTT/

Mark SALMON

Preferred Point Geometry and Statistical Manifolds

ECO No. 91/52

Costanza TORRICELLI

The Influence of Futures on Spot Price

Volatility in a Model for a Storable Commodity

ECO No. 91/53

Frank CRITCHLEY/Paul MARRIOTT/

Mark SALMON

Preferred Point Geometry and the Local

Differential Geometry of the Kullback-Leibler

Divergence

ECO No. 91/54

Peter MØLLGAARD/

Louis PHLIPS

Oil Futures and Strategic

Stocks at Sea

ECO No. 91/55

Christian DUSTMANN/

John MICKLEWRIGHT

Benefits, Incentives and Uncertainty

ECO No. 91/56

John MICKLEWRIGHT/

Gianna GIANNELLI

Why do Women Married to Unemployed Men have Low Participation Rates?

ECO No. 91/57

John MICKLEWRIGHT

Income Support for the Unemployed

in Hungary

ECO No. 91/58

Fabio CANOVA

Detrending and Business

Cycle Facts

ECO No. 91/59

Fabio CANOVA/

Jane MARRINAN

Reconciling the Term Structure of Interest Rates with the Consumption Based ICAP Model

ECO No. 91/60

John FINGLETON

Inventory Holdings by a Monopolist Middleman 
ECO No. 92/61

Sara CONNOLLY/John

MICKLEWRIGHT/Stephen NICKELL

The Occupational Success of Young Men

Who Left School at Sixteen

ECO No. 92/62

Pier Luigi SACCO

Noise Traders Permanence in Stock Markets:

A Tâtonnement Approach.

I: Informational Dynamics for the Two-

Dimensional Case 
ECO No. 92/61

Sara CONNOLLY/John

MICKLEWRIGHT/Stephen NICKELL

The Occupational Success of Young Men

Who Left School at Sixteen

ECO No. 92/62

Pier Luigi SACCO

Noise Traders Permanence in Stock Markets:

A Tâtonnement Approach.

I: Informational Dynamics for the Two-

Dimensional Case 


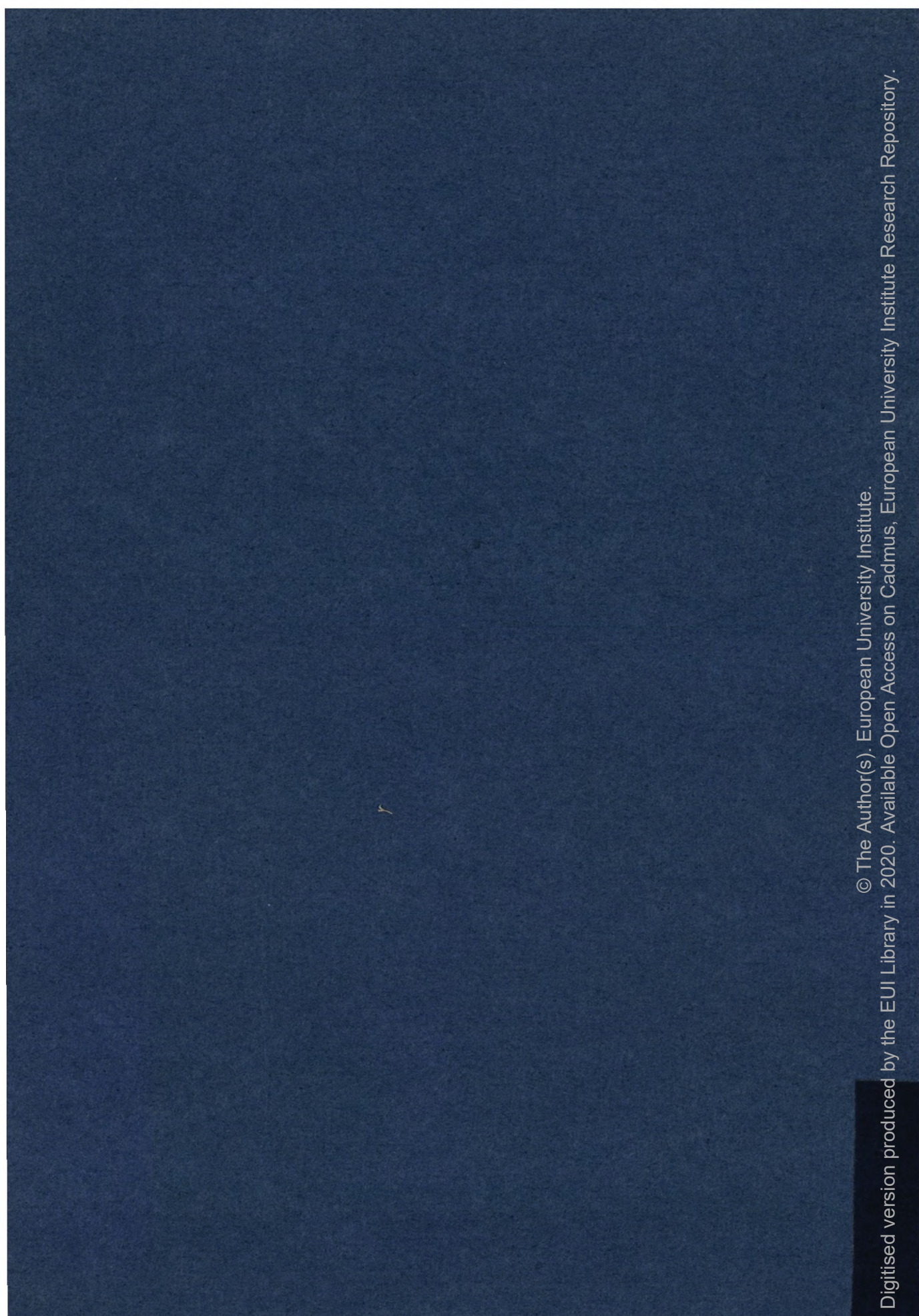

